\title{
Nükleer Tıpta Gama Kameraların Günlük Çalışma Verimini Belirlemede Kalite Kontrollerin Önemi: Paratiroid Sintigrafisi SPECT Çalışması Esnasında Gözlenen Fotoçoğaltıcı Tüp Defekti Vakası
}

\author{
Serdar Sedat Işı| $\mathbf{k}^{1,2} \odot$, Pelin Özcan Kara ${ }^{3} \odot$
}

${ }^{1} T$.C.Bilim Üniversitesi, Sağlık Hizmetleri Meslek Yüksekokulu, Tıbbi Hizmetler ve Teknikler Bölümü, Nükleer Tıp Teknikleri Programı, İstanbul, Türkiye

${ }^{2}$ T.C.Ankara Yıldırım Beyazıt Üniversitesi, Sağlık Bilimleri Enstitüsü, Radyoloji Anabilim Dalı, Sağlık Fiziği Y.L. Programı, Ankara, Türkiye ${ }^{3}$ T.C.Mersin Üniversitesi, Tıp Fakültesi, Nükleer Tıp Anabilim Dalı, Mersin, Türkiye

Serdar Sedat Işık, Öğr. Gör. Pelin Özcan Kara, Prof. Dr.

Illetişim:

Öğr. Gör. Serdar Sedat Işık

T.C.Bilim Üniversitesi, Sağılk Hizmetleri Meslek Yüksekokulu, Tibbi Hizmetler ve Teknikler Bölümü, Nükleer Tıp Teknikleri Programı, İstanbul, Türkiye Tel: +905546243809

E-Posta: serdar_sedat_1988@hotmail.com

Gönderilme Tarihi : 26 Temmuz 2017

Revizyon Tarihi : 02 Ekim 2017

Kabul Tarihi : : 04 Ekim 2017
ÖZET

Gama kameralarda planar görüntü kalitesinin belirlenmesinde en önemli unsur yapılan günlük kalite kontrol çalışmalarıdır. Gama kamera sistemlerinin görüntü kalitesinin bozulmasına neden olan sistemin yapısından ve dışarıdan kaynaklanan birçok etken vardır. Bu çalışmada, çift başlı SPECT yapabilen gama kameranın detektöründe gün içerisinde paratiroid sintigrafisi çalışması esnasında fotoçoğaltııı tüpte meydana gelen ve kameranın intrensek homojenitesinde değişikliğe yol açan fotoçoğaltıcı tüp defekti bulgularını sunduk ve günlük yapılan kalite kontrol testlerin nükleer tıp açısından önemini vurgulamayı amaçladık.

Anahtar sözcükler: nükleer tıp, gama kamera, kalite kontrol, kristal defekti, homojenite

THE IMPORTANCE OF QUALITY CONTROLS IN DETERMINING THE DAILY WORKING EFFICIENCY OF NUCLEAR ENVY GAMMA CAMERAS: PARATHYROID SCINTIGRAPHY OBSERVED PHOTOMULTIPLIER TUBE DEFECT CAUSE DURING SPECT STUDY

\section{ABSTRACT}

The most important factor in determining the planar gamma camera image quality is daily quality control studies. There are many factors including the structure of the system and factors arising from the outside that cause degradation of the image quality. In this case report, we present the findings of photomultiplier tube defect which led to changes in the homogeneity that was detected during parathyroid scintigraphy scanning on a dual-headed SPECT gamma camera and we aimed to emphasize the importance of daily quality control tests for nuclear medicine department.

Keywords: nuclear medicine, gamma camera, quality control, crystal defect, homogeneity

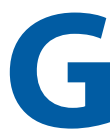
ama kameralar insan vücuduna verilen radyofarmasötiklerin dağılımını görüntülemeye yarayan araçlardır. Bu cihazlar hasta üzerinde bulunan radyoaktif maddelerin yaydığı gama radyasyonunu algılayarak hastaların fizyolojik ve biyokimyasal süreçleri hakkında bilgi verir. Bu bilgiler hastanın hastalığının tanısı, tedavi planlaması ve takibi bakımından önemlidir. Hastalıkların tanısına yönelik olarak doğru klinik bilgilerin elde edilmesi için görüntüleme sisteminin performansındaki değişimlerin hasta görüntülemesinden önce ortaya çıkartılması ve gerekli 
düzenlemelerin yapılması büyük önem taşımaktadır. Bu işlemlerin tamamı kalite kontrol çalışmaları ile gerçekleştirilmektedir (1). Gama kameraların düzgün çalışmaması durumunda hastalar için faydalı ve kaliteli bir işlem sağlanamamasının yanında bu durumdan hastanın büyük ölçüde zarar görmesi de olası bir durumdur. Sağlık hizmetlerinde doktorların başarısının büyük ölçüde çalışma şartları ve ortamına bağlı olduğu belirtilmektedir (2). Nükleer tıp görüntülemenin temel unsurlarından olan gama kameraların kalite kontrol işlemleri ile düzenli olarak test edilmesi gerekir. Gama kameraların kalite kontrol işlemlerinin geliştirilmesi, standart uygulamalarının ve kabul kriterlerinin belirlenmesi için birçok uluslararası kurumlar tarafından yönergeler oluşturulmuştur. Avrupa nükleer tıp derneği fizik komitesinin son yıllarda yayınlamış olduğu nükleer tıp cihazlarının kabul testleri ile ilgili yönerge (3) ve nükleer tıp cihazlarını rutin kalite kontrol testlerine yönelik önerileri (4) bu konuda önemli referanslardandır.

Bu vaka sunumunda bir üniversitenin tıp fakültesi hastanesi nükleer tıp anabilim dalında bulunan çift başı SPECT yapabilen gama kameranın 1 numaralı detektöründe gün içerisinde 25 numaralı fotoçoğaltıcı tüpünde meydana gelen ve kameranın intrensek homojenitesinde değişikliğe yol açan fotoçoğaltıc tüp defekti sorununu örnek göstererek günlük yapılan kalite kontrollerin nükleer tıp açısından önemini vurgulamayı amaçladık.

\section{Vaka sunumu}

Nükleer tıp bölümünde günlük çalışma öncesi çift başlı gama kamerada yapılan peaking/tuning testleri ile intrensek ve ekstrensek homojenite testinin görsel ve kantitatif olarak normal olduğu (Şekil $1 \mathrm{~A}$ ve B) bir çalışma gününde arka arkaya iki tane paratiroid sintigrafisi tetkiki yapıldı. Paratiroid sintigrafisi uygulaması, Türkiye Nükleer Tıp Derneği Paratiroid Sintigrafisi Uygulama Kılavuzu (5) dikkate alınarak yapıldı. Hastalara $20 \mathrm{mCi}$ Tc99m MIBI intravenöz olarak verildi. Tc ${ }^{99 m}$ MIBI miyokard perfüzyon ajanı olarak geliştirilmesine rağmen birçok tümörde olduğu gibi paratiroid adenomlarında da tutulur, enjeksiyondan hemen sonra yaklaşık 5 dakikadan daha az bir süre içinde hem paratiroid adenomunda hem de tiroid dokusunda

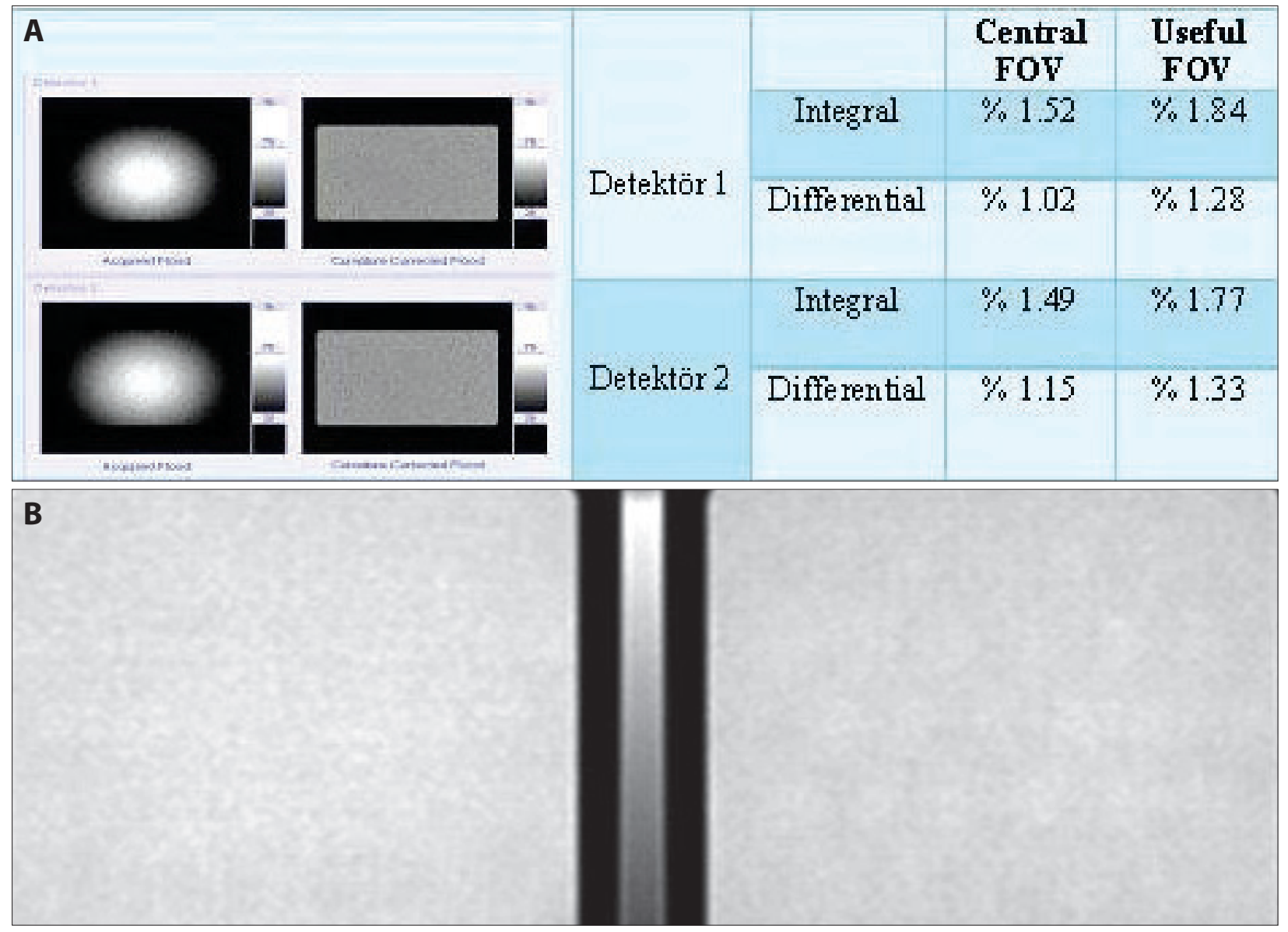

Şekil 1. Gün içerisinde çalışmalara başlamadan önce (a) 30 milyon sayım ile yapılan intrensek homojenite testi ve (b) görsel olarak kolimatör hasarını tespit edip değerlendirmek için 20 bin sayım ile yapılan ekstrensek homojenite testi. 
tutulur. Tc ${ }^{99 m}$ MIBI nispeten hızıı bir şekilde atıldığı (2-3 saat) normal tiroid dokusundan farklı olarak paratiroid adenomundan atılımı yavaştır. Bu nedenle enjeksiyondan daha ileri bir saatte olası paratiroid adenomunun daha iyi lokalizasyonu ve boyun-toraks bölgesinin daha net görüntülenmesi amacıyla geç SPECT görüntülemesi (120.dk) yapılabilir. Bununla birlikte SPECT görüntüleme istenirse radyoaktif madde enjeksiyonundan sonra erken (20.dk) ve geç (120.dk ve hatta 180.dk, 240.dk) devrelerde alınabilir. Enjeksiyondan sonra hastaların 20.dakikada ve 120.dakikada baş-boyun-mediasten bölgesinden 5'er dakikalık planar görüntülemesi ve 120.dakika planar görüntüleme sonrasında aynı bölgeden paratiroid SPECT görüntülemesi yapıldı. Her iki hasta için 20.dakikada ve 120.dakikada 5'er dakika alınan planar görüntülerin normal olduğu görüldü (Şekil $2 A, B, C$ ve D). Hastaların enjeksiyondan 120 dakika sonra 5 dakikalık planar görüntülemesinden hemen sonra yapılan paratiroid sintigrafisi SPECT çalışması esnasında 1 numaralı detektörde, alınan görüntülere yansıyan ve görüntülerde sağ üst bölgede (detektöre göre sol üst kadran) hiç sayım alınamayan bir alan olduğuna dikkat edildi (Şekil 3A ve B). Görüntülere yansıyan bu kusurun ilgili alana denk eden fotoçoğaltıcı tüpte defekt olduğu şüphesini akıllara getirdi. Bunun sonucunda diğer görüntüleme işlemlerine ara verilerek kalite kontrol testleri yinelendi. Yapılan peaking/tuning testlerinde peaking işleminin yapıldığı ancak tuning işleminin yapılamadığı görüldü. Tekrarlanan intrensek ve ekstrensek homojenite testinde ise (Şekil 4A,B ve C) 1 numaralı detektörde nonhomojeniteye yol açan belirgin bir tüp defekti saptandı (Intrensek: UFOV \%99.93, CFOV \%66.60). Teknik servis mühendislerine durumun bildirilmesi üzerine yapılan kalite kontrollerde 1 numaralı detektördeki sorunun ilgili alana denk gelen 25 numaralı fotoçoğaltıc tüpte, tüp defekti

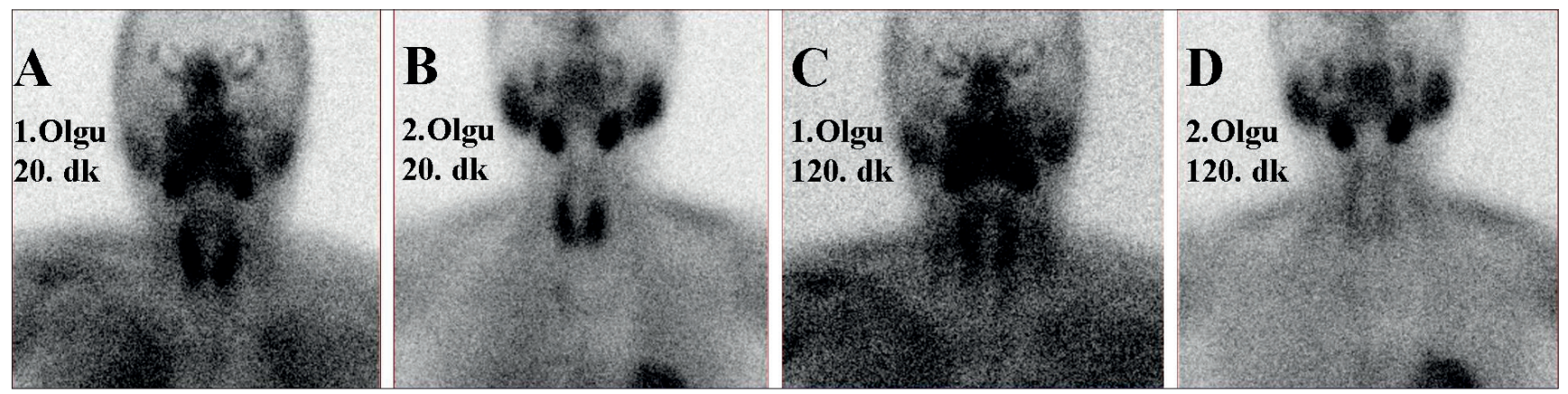

Şekil 2. Paratiroid sintigrafisi tetkiki yapılan 1. (erkek) ve 2. (kadın) hastanın (a) birinci hastanın enjeksiyondan 20 dakika sonra, (b) ikinci hastanın enjeksiyondan 20 dakika sonra, (c) birinci hastanın enjeksiyondan 120 dakika sonra ve (d) ikinci hastanın enjeksiyondan 120 dakika sonra baş-boyun-mediasten bölgesinden gama kamera ile anteriordan alınan 5 dakikalık planar görüntüleri.
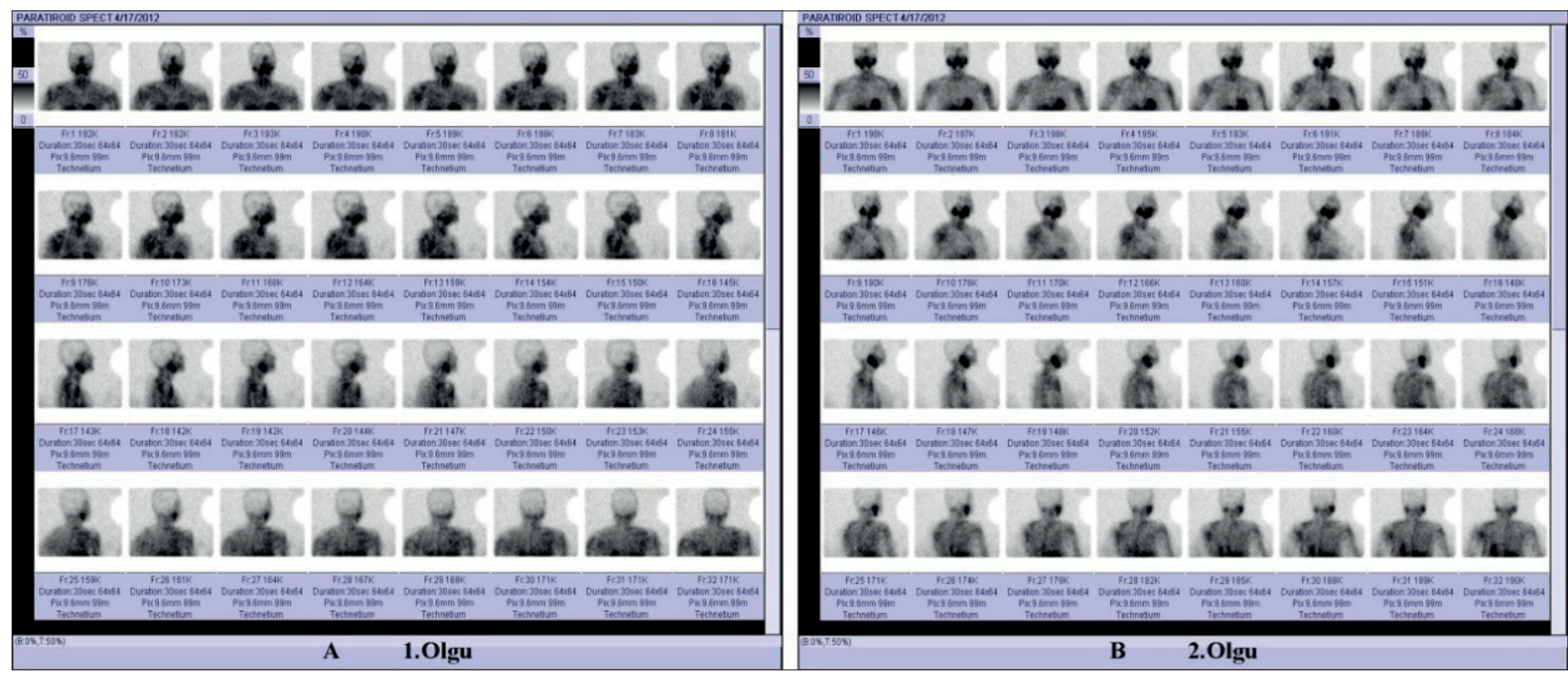

Şekil 3. Paratiroid sintigrafisi yapılan (a) birinci hastanın ve (b) ikinci hastanın, 20 mCi Tc-99m MIBI enjeksiyonundan 120 dakika sonra baş-boyun bölgesinden yapılan paratiroid SPECT çalışması görüntüleri ve 1.detektör ile elde edilen görüntülerde sağ üst bölgede sayım alınamayan ve fotoçoğaltıcı tüp defekti olduğunu düşündüren yarım daire şeklindeki ilgili alan. 


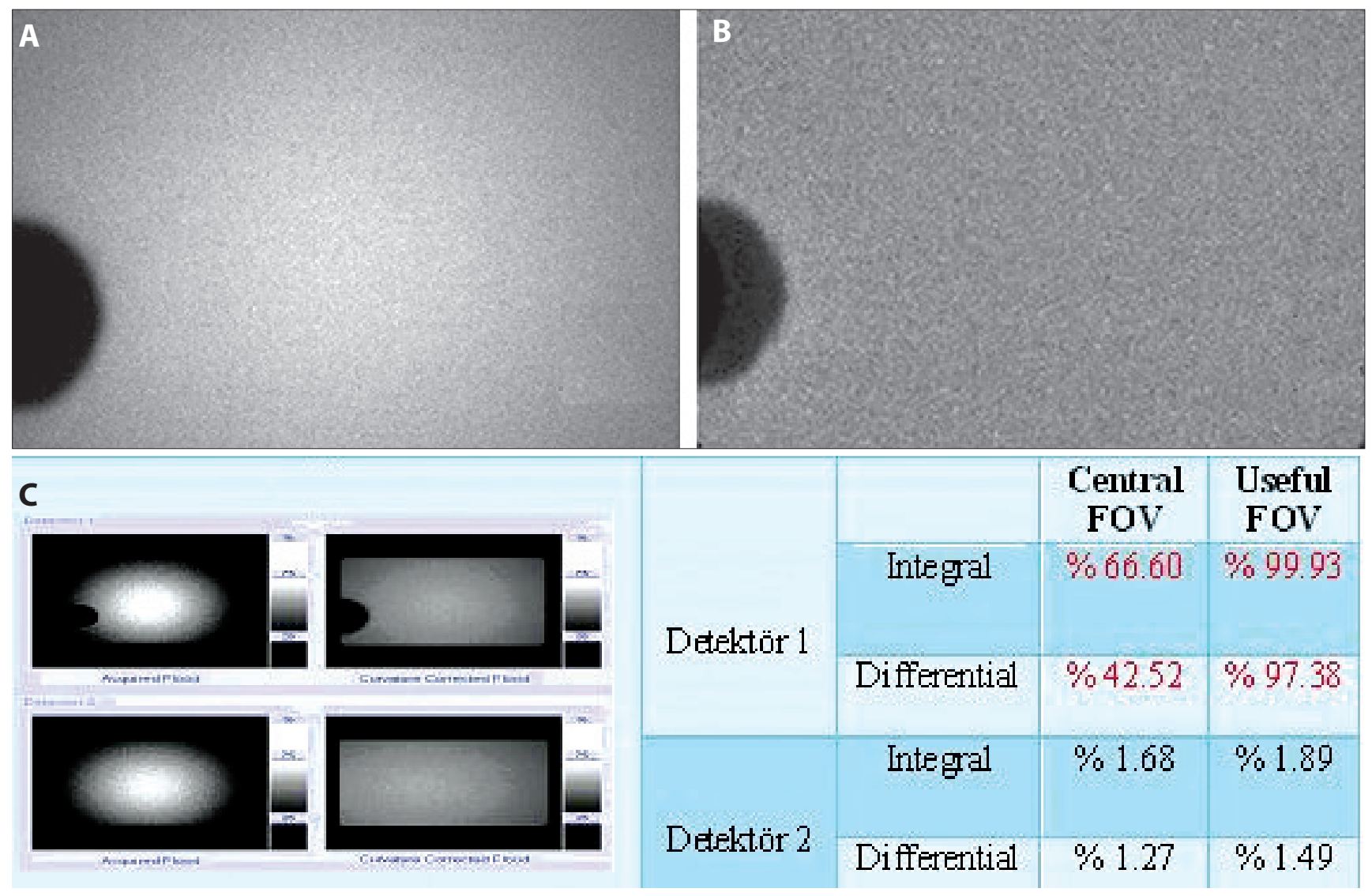

Şekil 4. Paratiroid SPECT çalışmasında görüntülere yansıyan ve fotoçoğaltıcı tüp defektini akıllara getiren gama kamerada yapılan kalite kontrollerde (a) intrensek homojenite çalışmasında 30 milyon sayım ile elde edilen homojenite ve defekt görüntüsü, (b) düşük enerji yüksek rezolüsyon (LEHR) kolimatörü takılı iken yapılan ekstrensek homojenite çalışmasında 5 bin sayım ile elde edilen homojenite ve defekt görüntüsü ve (c) her bir detektörü için 30 milyon sayım ile intrensek homojenite testi yapılan gama kamerada elde edilen görüntü (1.detektörde homojen olmayan 2.detektörde homojen olan) ve her bir detektör için kantitatif homojenite değerleri.

problemi olduğunu kesinleştirdi. İlgili fotoçoğaltıcı tüp yenisi ile değiştirilerek (Şekil 5) peaking/tuning işlemi yapılarak hemen arkasından yapılan intrensek ve ekstrensek homojenite testinde nonhomojenitenin düzelerek homojen bir görüntünün elde edildiği görüldü (Şekil $6 \mathrm{~A}$ ve B).

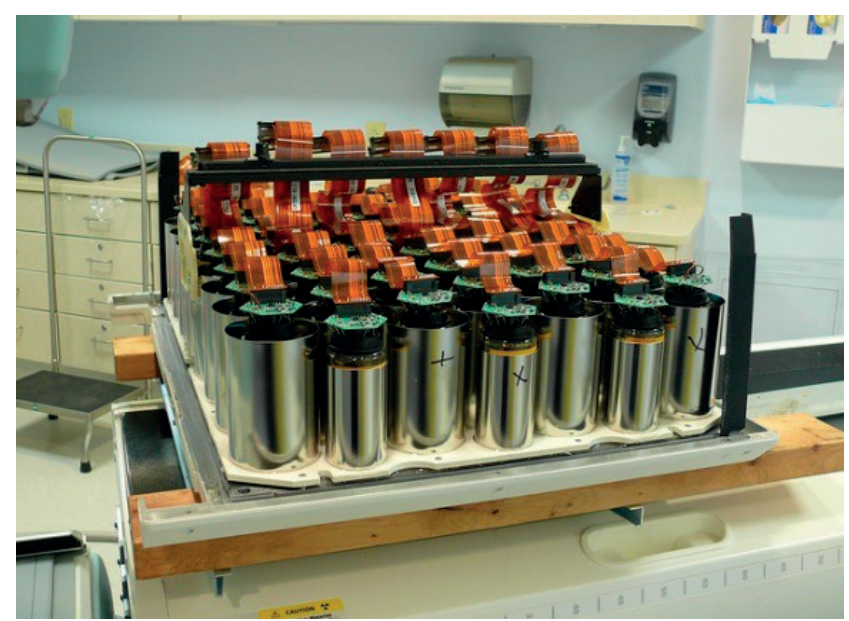

Şekil 5. Defekt tespit edilen gama kameranın ilgili fotoçoğaltıcı tüpünün yenisi ile değiştirilmesi.

\section{Tartışma ve sonuç}

Nükleer tıp uygulamalarında cihaz performansları ile ilgili kalite standartlarının sağlanması son derece önemlidir. Nükleer tıp alanında görüntülemenin temel araçlarından birisi olan gama kameralarının düzenli olarak kalite kontrol testleri ile değerlendirilmesi doğru inceleme sonuçları elde edebilmenin ve hatalı sonuçlardan kaçınabilmenin öncelikli koşuludur. Gama kameraların kalite kontrol işlemleri cihazların kurulumu aşamasında başlar. Bir gama kameranın kurulumunda yapılan ilk kontrol testleri 'kabul testleri' olarak adlandırımaktadır. Kabul testleri, uluslararası standartlar ile belirlenen değerler içerisinde kalmak kaydıyla imalatçı firmalar tarafından bildirilir. Bu testlerde elde edilen sonuçların kaydı tutulur ve üretici firma bu sonuçları müşterisine verir. Üretici firma daha sonra kameranın kurulduğu yerde, ilgili medikal fizikçinin kontrolünde gerekli yazılımları ve fantomları sağlayarak kabul testlerinin tamamını yeniden yapar. Kabul testlerinin NEMA (National Electrical Manufacturers Association) kriterlerine uygun olması beklenir $(4,6)$. Hangi kalite kontrol 


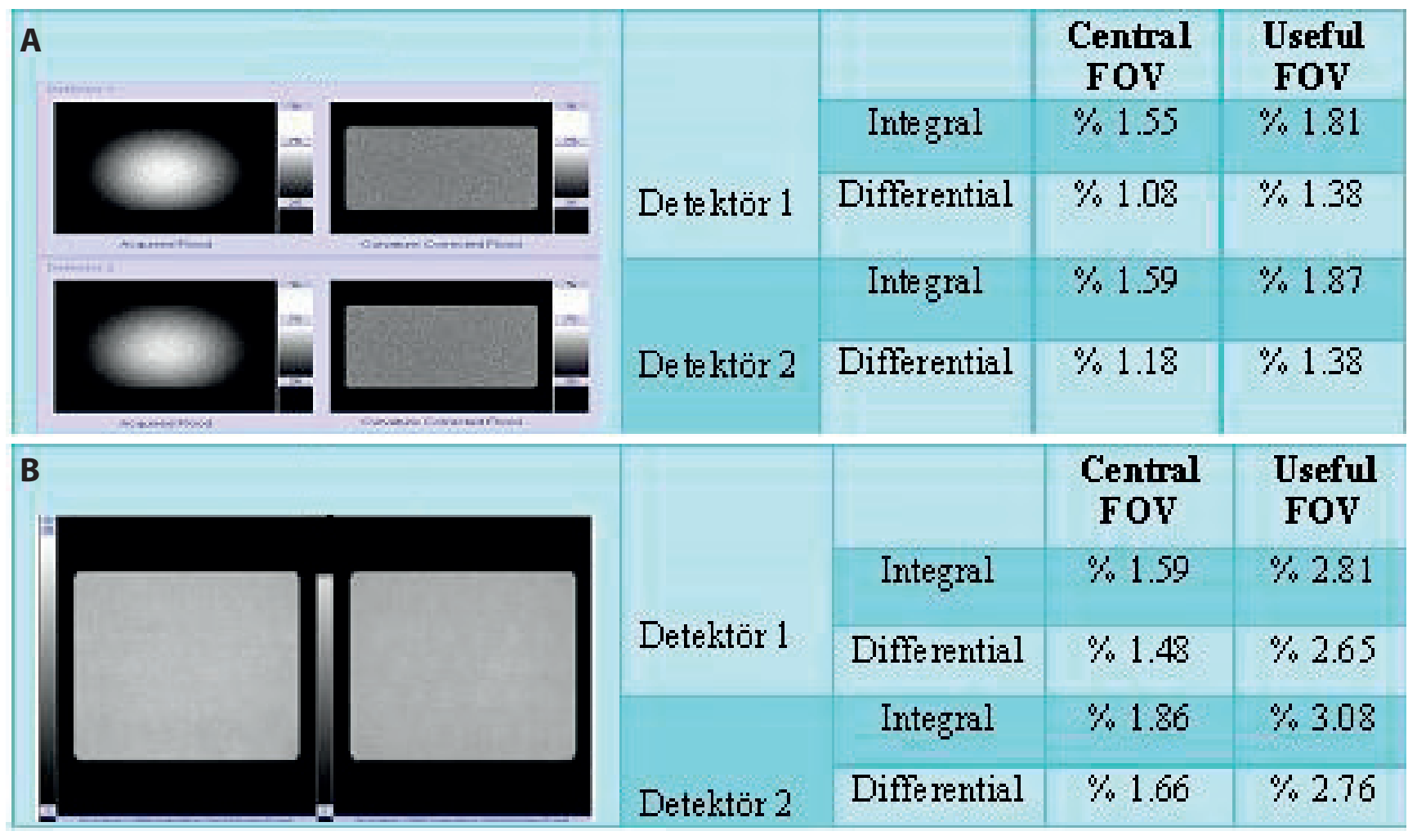

Şekil 6. Gama kameranın 1 numaralı detektöründe defekt tespit edilen fotoçoğaltıcı tüpün yenisi ile değiştirilmesinden sonra yapılan kalite kontroller ile elde edilen homojenite görüntüleri ve kantitatif homojenite sonuçları; (a) 30 milyon sayım ile yapılan intrensek homojenite çalışması ve (b) gama kamera detektörlerinde düşük enerji yüksek rezolüsyon (LEHR) kolimatörü takılı iken 120 milyon sayım ile yapılan ekstrensek homojenite çalışması.

işlemlerinin hangi sıklıklarla uygulanması gerektiği çeşitli yönergelerde (4) ele alınmış olsa da, her bir gama kameraya uygulanması gereken kalite kontrol işlemleri, kameranın teknik özelliklerine, kullanım biçimine ve kullanıldığı ortama göre değişkenlik gösterir. Tüm bu değişkenleri dikkate alarak her bir gama kamera için özel bir kalite kontrol programı oluşturulması gerekir. Cihazın kabulünden sonra elde edilen kontrol değerleri ilk standartlar ile karşılaştırılır. Elde edilen her bir kalite kontrol değerleri bir önceki değerler ile karşılaştırılır. Ayrıca tüm kalite kontrol testi sonuçlarının kaydedilmesi, kamera performansında meydana gelebilecek değişikliklerin saptanması ve sorunların giderilmesi bakımından önem taşır $(1,7,8)$.

Gama kamera sisteminin görüntü kalitesinin bozulmasına neden olan birçok etken vardır. Temel olarak gama kamera sisteminin performansı sistemin yapısından ve dışarıdan kaynaklanan çeşitli etkilerle azalır. Gama kamera sisteminin performansını etkileyen belli başlı dış etkenler: kolimatör hasarı, foton çoğaltıcı tüplerin zamana bağIı değişimleri, enerji pikinin kayması, elektronik gürültü, kristal ve ışık geçirgen tabakadaki kusurlar, kolimatör ve yüzeylerdeki bulaş ve manyetik alan şeklinde sıralanabilir. Görüntüleme sisteminin performansındaki değişimler ve dışarıdan kaynaklanan etkilerle görüntü istenilen kalitede elde edilmez. Gama kamera performansındaki bu değişimler klinik çalışmalar sırasında fark edilemeyebilir ve bu durum hastalara ait görüntülerin değerlendirilmesi sırasında önemli bir hata kaynağı olabilir. Bu nedenle görüntü yorumlamasını olumsuz etkileyecek durumların hasta görüntülemesinden önce kalite kontrol çalışmaları ile ortaya çıkarılması son derece önemlidir $(1,7,8,9)$.

Bu olgu sunumunda, çift başlı gama kamera sisteminde günlük hasta alımına başlanmadan önce yapılan kalite kontrol testlerinin normal olduğu bir çalışma gününde paratiroid sintigrafisi tetkiki yapılan iki hastanın SPECT çalışmasında 1 numaralı detektörde görüntülere yansıyan ve bu detektörün intrensek homojenitesinde değişikliğe yol açan fotoçoğaltıcı tüp defekti sorunu, yapılan kalite kontrol testleri ve görüntüler eşliğinde takdim edilmiştir. Gama kameranın 1 numaralı detektörü fotoçoğaltıcı tüpünde meydana gelen ve paratiroid SPECT çalışmasında görüntülere yansıyan defekt çeşitli homojenite çalışmalarıyla tespit edilerek ortaya konmuştur.

Gama kamerada hasta alımına başlanmadan önce bir godeye $30 \mu \mathrm{Ci}$ Tc-99m kalite kontrol nokta kaynağı 
hazırlanmış ve her iki detektörden ayrı ayrı 30 milyon sayım toplanacak şekilde intrensek homojenite çalışması yapılmıştır. Yapılan intrensek homojenite çalışmasında her iki detektörde elde edilen görüntünün görsel olarak homojen olduğu ve kantitatif homojenite değerlerinin de görsel sonuçları desteklediği, kantitatif homojenite değerlerinin \%1.02 ile \%1.84 arasında değerler aldığı görülmüştür (Şekil 1 A). Aynı zamanda gama kamerada düşük enerji yüksek rezolüsyon (LEHR) kolimatörü takılı iken meydana gelmiş olabilecek kolimatör hasarının görsel tespiti ve kolimatörle beraber detektörlerin homojenitesini belirlemek maksadı ile 15 mCi aktiviteli düzlemsel Co-57 kaynağı kullanılarak her bir detektörden 20 bin sayım toplanarak ekstrensek homojenite testi yapılmıştır. Ekstrensek homojenite testi ile elde edilen görüntünün görsel olarak homojen olduğu ve ayırt edilebilir bir kolimatör hasarının olmadığı görülmüştür (Şekil 1 B). Gün içerisinde gama kamerada hasta alımına başlanmış ve mevcut olan hastalardan alınan planar görüntülerde sorun teşkil edecek anormal bir durum gözlenmemiştir. Paratiroid sintigrafisi çalışmasında da hastalardan alınan planar görüntülerin normal olduğu görülmüştür (Şekil 2 A,B,C ve D). Ancak bu hastalarda yapılan paratiroid sintigrafisi SPECT çalışmasında 1 numaralı detektörde, alınan görüntülere yansıyan ve görüntülerde sağ üst bölgede (detektöre göre sol üst kadran) hiç sayım alınamayan bir alan olduğu medikal fizik uzmanı tarafından görülmüştür (Şekil $3 A$ ve B). Paratiroid sintigrafisi SPECT görüntüleri incelendiğinde 1 numaralı detektör ile elde edilen görüntülerdeki bu kusurun ilgili alana denk gelen fotoçoğaltıcı tüpte defekt olduğu düşüncesini akıllara getirmiştir. İlgili kusur tiroid/paratiroid gibi organ görüntülerinin üzerinde yer almıyordu ancak miyokard perfüzyon görüntüleme, akciğer görüntüleme, böbrek görüntüleme, kemik görüntüleme vb. gibi tetkiklerde ciddi bir problem kaynağı olabilirdi. Hatta kemik sintigrafisi ve diğer uygulamalarında sıklıkla yapılabilen SPECT çalışmasında, ilgilenilen bölgede ilgili fotoçoğaltıcı tüp defektinin denk geldiği alanlarda bu problem lezyonların gözden kaçmasına neden olabilirdi. Belli kusurlar tekniker ya da ilgili uzman tarafından fark edilemeyebilir, bu durum ise ilgilenilen bölgede lezyonların gözden kaçmasına, ilgilenilen organ ya da bölgelerde bilgi kaybına neden olarak yanlış veya eksik raporlamaya neden olabilir. Fotoçoğaltıcı tüp defekti kusurları, çekimi gerçekleştiren tekniker tarafından çekim yapılırken ya da çekim sonrasında ham görüntüler, yeniden oluşturulan görüntüler incelenerek fark edilebilir. Bu durum teknikerin bilgi ve deneyimi ile de alakalı bir durumdur. Bu tip problemlerin teknikerin gözünden kaçması durumunda, ilgili uzman eksik bilgiler içeren görüntülerle karşılaşabilir, bu eksikliği fark edemeyebilir. İlgili uzman ya da klinisyen bu kusurun farkına varsa bile hastanın görüntülerini yorumlamada zorlanabilir hatta yorumlayamayabilir. Çekimi gerçekleştiren tekniker ve ilgili uzman, çekimin yapıldığı ilgili alanlarda görüntülerin genel kontrast farklılıklarına dikkatle bakarak, hiç foton sayımının alınmadığı hipoaktif görünümlü alanlarda fotoçoğaltıcı tüp defekti kusurunu fark edebilirler. Fotoçoğaltıcı tüp defektine bağlı olarak meydana gelebilecek bir homojenite bozukluğu, kemik sintigrafisi uygulamasında fark edilmeyebilir ve yanıltıcı sonuçlar verebilir. Bu yanıltıcı sonuçlar ise klinisyen tarafından hastanın raporunun yanlış bildirilmesine neden olabilir. Bizim çalışmamızda fotoçoğaltıı tüp defekti ve görüntülere yansıması, çekim sırasında medikal fizik uzmanı tarafından fark edilmiş ve hastaların görüntüleri kontrol edilerek ilgilenilen organlarla alakalı bir bilgi kaybı olmadığından emin olunarak işlemler tamamlanmıştır. Bu düşünce ile kalite kontrol intrensek ve ekstrensek homojenite testi ile detektörlerin homojenitesi tekrar test edilmiştir (Şekil $4 \mathrm{~A}, \mathrm{~B}$ ve C). $30 \mu \mathrm{Ci}$ TC- $99^{\mathrm{m}}$ radyoaktif nokta kaynağı kullanılarak 30 milyon sayım ile yapılan intrensek homojenite çalışmasında faydalı görüş alanı (UFOV) ve merkezi görüş alanı (CFOV) için integral ve diferansiyel homojenite değerlerinin 1 numaralı detektör için \%42.52 ile \%99.93 arasında değiştiği ve görsel olarak homojen olmadığı, 2 numaralı detektör için ise homojenite değerlerinin \%1.27 ile \%1.89 arasında değerler aldığı ve görsel olarak homojen olduğu görülmüştür. 2 numaralı detektör için kantitatif homojenite değerlerinin NEMA standardı olan \%2.5-3.5 değerlerinin altında olduğu görülmüştür. Detektör 1 için elde edilen kantitatif homojenite değerleri incelendiğinde sonuçların oldukça yüksek olduğu ve bu değerlerin NEMA standardı olan üst sınır değerlerini aştığı görülmektedir.

Benzer şekilde 1 numaralı ve 2 numaralı detektöre ait olan faydalı görüş alanı ve bu alanın \%75'ine karşılık gelen merkezi görüş alanı içerisindeki integral ve diferansiyel homojenite değerleri her iki detektör için kıyaslanarak değerlendirildiğinde 1 numaralı detektöre ait olan homojenite değerlerinin 2 numaralı detektörün homojenite değerlerine göre oldukça yüksek olduğu görülmüştür. Bu durumun nedeni ise 2 numaralı detektörde intrensek homojenite görüntüsü ve kantitatif homojenite değerleri normal ve kabul edilebilir olmasına rağmen 1 numaralı detektörde 2 numaralı detektöre göre homojen olmayan ve kantitatif homojenite değerlerinin oldukça yüksek çıkmasına sebep olan, detektörün sol üst yan kadranına denk gelen alanda fotoçoğaltıcı tüp defektinin olmasıdır. Bundan dolayı görüntülerde 1 numaralı detektörün sol üst yan kadranında görünen yarım ay şeklindeki siyah alana karşılık gelen kısımdaki fotoçoğaltıı tüpte hiç sayım alınamadığı için 1 numaralı detektörün kantitatif homojenite değerleri 2 
numaralı detektörün kantitatif homojenite değerlerine göre daha yüksek çıkmıştır (Şekil 4 C). Bununla birlikte LEHR kolimatörü takılı iken 1 numaralı detektörde düzlemsel Co-57 kaynağı ile yapılan ekstrensek homojenite çalışmasında 5 bin sayım ile elde edilen homojenite ve defekt görüntüsü tekrar teyit edilmiştir (Şekil 4 B). Gama kameranın faydalı görüş alanı (UFOV) ve bu alanın \%75 küçültülmüş değerine karşılık gelen merkezi görüş alanı (CFOV) önemlidir. Fotoçoğaltıcı tüp defektinin kamera detektöründe bulunduğu konum ve yere göre kameranın kullanım şekli değişecektir. Örneğin; fotoçoğaltıcı tüp defektinin kamera detektörünün merkezinde meydana gelmesi hem faydalı görüş alanının hem de merkezi görüş alanının integral ve diferansiyel homojenite değerlerinin oldukça yüksek çıkmasına neden olacaktır. Bu durumda kamera görüş alanı (FOV) ne kadar küçültülse de kamera diğer günlerde sağlıklı bir şekilde kullanılamayacaktır. Bizim vakamızda ise fotoçoğaltıcı tüp defekti detektörün en dış yan kadranında meydana gelmişti ve buna rağmen faydalı görüş alanı ile birlikte merkezi görüş alanı integral ve diferansiyel homojenite değerleri yüksekti. Bizim karşılaştığımız fotoçoğaltıcı tüp defekti kusuru için diğer günlerde kamera görüş alanı küçültülerek belli küçük organların görüntülemesi yapılabilirdi ancak sağlıklı ve güvenilir gama kamera çalışmalarının yürütülebilmesi için homojenite bozukluğu problemlerinin giderilerek çalışmaların yürütülmesi gerekmektedir.

Çeşitli firmalar düzeltilmiş homojenite değerlerinin $\% 5^{\prime} \mathrm{e}$ kadar kabul edilebileceğini bildirmelerine rağmen NEMA standartlarına göre $\% 2,5^{\prime}$ ten küçük olmalıdır. Gama kameranın kalite kontrol intrensek homojenite çalışmalarında elde edilen homojenite değerleri çok yüksek çıkmış ve tekrarlanan homojenite çalışmalarında da benzer değerler elde edilmiştir. Kabul edilebilir homojenite değerlerinin maksimum $\% 2,5$ olması gerektiği bilindiğinden ve 1 numaralı detektördeki 25 numaralı fotoçoğaltıcı tüp defekti kusuru tespit edildiğinden, kusurlu fotoçoğaltıcı tüp materyali değiştirilerek yenilenmiştir (Şekil 5). Yinelenen kalite kontrol intrensek ve ekstrensek homojenite çalışmalarında görsel ve kantitatif olarak elde edilen sonuçlar değerlendirildiğinde her bir detektör için elde edilen görüntülerin homojen olduğu ve kantitatif integral ve diferansiyel homojenite değerlerinin ise intrensek homojenite testi için $\% 1,18$ ile $\% 1,87$ değerleri arasında olduğu, ekstrensek homojenite testi için ise \%1.48 ile \%3.08 değerleri arasında olduğu; bu sonuçların NEMA'nın standartları içerisinde olduğu ve belirlenen referans değerlerinin altında olduğu görülmüştür (Şekil 6 A ve B).

Gama kameraların birçoğunun yapısında; gama fotonunu görünür ışığa dönüştürmede görev alan sintilasyon kristali (çoğunlukla talyum intiva edilmiş sodyum iyodür$\mathrm{Nal}(\mathrm{TI})$ ) ve fotoçoğaltıcı tüpler bulunmaktadır. Bu tip gama kameralarda kristal ve fotoçoğaltıcı tüp defekti ile karşılaşılması olası bir durumdur. Bununla birlikte son yıllarda detektör teknolojisindeki gelişmeler yarı iletken detektörler üzerinde yoğunlaşmış olup, rutin uygulamalarda yerini almaya başlamıştır. Yeni olan solid state yarı iletken detektör sistemli gama kameralarda sintilasyon kristali ve fotoçoğaltıcı tüpler bulunmayabilmektedir, yarı iletken detektöre gelen gama ışını direkt elektrik sinyaline çevrilmektedir. Dolayısı ile solid state yarı iletken detektörlü, yapısında fotoçoğaltıcı tüp bulunmayan sistemlerde elde edilen görüntülerde fotoçoğaltıcı tüpe bağlı bu tip defekt ve kusurlar ile karşılaşılmayacaktır.

Hastalıkların tanısına yönelik olarak doğru klinik bilgilerin elde edilmesi için görüntüleme sisteminin performansındaki değişimlerin hasta görüntülemesinden önce ortaya çıkartılması ve gerekli düzenlemelerin yapılması büyük önem taşımaktadır. Yapılan işlemlerin tamamı kalite kontrol çalışmaları ile gerçekleştirilmektedir. Nükleer Tıp alanında görüntülemenin temel araçlarından birisi olan gama kameralarının düzenli olarak kalite kontrol testleri ile değerlendirilmesi doğru inceleme sonuçları elde edebilmenin ve hatalı sonuçlardan kaçınabilmenin öncelikli koşuludur. Gama kameralarda günlük kalite kontroller cihazların kalite güvenliğinin sürekliliği için mutlaka günlük çalışma öncesi yapılmalı ve detektörlerin homojenitesinden şüphe duyulduğu takdirde gün içerisinde tekrarlanmalıdır. Bu bağlamda, sunduğumuz bu vaka sunumunun akılda tutulması faydalı olabilir. 


\section{Kaynaklar}

1. Değer, M., Demir, M., İnce, M., Kıraç, S., Köseoğlu, K., Turan, E. et al, Kalite Kontrol, Enstrümantasyon ve Radyasyon Güvenliği Komitesi Yönergesi, Turkish J Nucl Med 2004;13:118-39.

2. Lucignani, G., Del Sole, A., Nuclear medicine: what kind of quality would we want if we were the patient? Eur J Nucl Med Mol Imaging 2010;37:2194-8.

3. Busemann Sokole, E., Plachcinska, A., Britten, A., Acceptance testing for nuclear medicine instrumentation., Eur J Nucl Med Mol Imaging 2010;7: 672-81. [CrossRef]

4. Busemann Sokole E., Plachcinska A., Britten A., Lyra Georgosopoulou M., Tindale W., Klett R., Routine quality control recommendations for nuclear medicine instrumentation. Eur J Nucl Med Mol Imaging 2010; 7:3: 662-71. [CrossRef]
5. Varoğlu, E. ve ark., Türkiye Nükleer Tıp Derneği Endokrinoloji ve Radyonüklid Tedavi Çalışma Grubu Paratiroid Sintigrafisi Uygulama Kılavuzu, Turk J Nucl Med 2001;10:32-9.

6. Early P.J., Planer imaging. In: Early PJ Sodee DB (eds). Principles and practice of nuclear medicine, seconnd ed. Mosby-Years Book, inc. St. Louis, 1994: 251-90.

7. Vanregemorter J., The gamma camera quality control and quality assurance, Europan Nuclear Medicine Congress, the book of technologists sessions, 1995

8. Demir M., Gama Kameralarda Kalite Kontrol Testleri, Türkiye Nükleer Tıp Dergisi, 2001, 10:217-27.

9. Demir, M., Nükleer Tıp Fiziği ve Klinik Uygulamaları, 2011, 3.baskı, İstanbul Üniversitesi Cerrahpaşa Tıp Fakültesi Nükleer Tıp Anabilim Dalı, İstanbul. 